\title{
Sosialisasi Pencegahan Penularan Covid-19 dan Bantuan Penguatan Ekonomi Masyarakat Terdampak Kota Banda Aceh
}

\author{
Bunyamin $^{1}$, Lindawati ${ }^{2}$, Amalia $^{3}$, Mery Silviana ${ }^{4}$, Dewi Maya Sari ${ }^{5}$ \\ ${ }^{1}$ Jurusan Teknik Sipil, Universitas Iskandar Muda \\ ${ }^{2}$ Jurusan Teknik Mesin, Universitas Abulyatama \\ ${ }^{3}$ Jurusan Teknik Sipil, Universitas Abulyatama \\ ${ }^{4}$ Jurusan Teknik Sipil, Universitas Al Muslim \\ ${ }^{5}$ Jurusan Akuntansi Sektor Publik, Politeknik Aceh
}

Email: merysilviana85@gmail.com

\begin{abstract}
The beginning of 2020 is a new challenge for all countries affected by Covid 19, including Indonesia. The number of cases that continues to grow is a public concern. Even so, there are still many people who do not care about the dangers of the virus. Not only physically and psychologically, this global case also affects the economic condition of the community. One of the communities affected by the economy due to the Covid-19 pandemic is the people of Surien Village, Banda Aceh. This service activity aims to disseminate the prevention of Covid-19 transmission and assistance to strengthen the economy of the affected community in Surien Village, Meuraxa District, Banda Aceh City. The method used is to educate the public about health protocols that have been issued by the government to prevent transmission of the corona virus. Socialization was carried out by practicing and distributing brochures containing detailed health protocols such as wearing masks, physical distance from crowds and proper and proper hand washing methods tucked into the basic needs assistance. The results of these activities provide a deeper understanding to the public about the importance of wearing masks and washing hands properly for the early prevention of the spread of Covid-19. Providing basic food assistance is very useful for strengthening the economy of people who tend to be unprivileged during the Covid-19 pandemic issue.
\end{abstract}

Keywords: Covid 19, education, economic assistance, Banda Aceh

\section{Pendahuluan}

Penyakit coronavirus (COVID-19) adalah penyakit menular yang disebabkan oleh coronavirus yang baru ditemukan. Sebagian besar orang yang terinfeksi virus COVID-19 akan mengalami penyakit pernapasan ringan hingga sedang dan sembuh tanpa memerlukan perawatan khusus. Orang yang lebih tua, dan mereka yang memiliki masalah medis mendasar seperti penyakit kardiovaskular, diabetes, penyakit pernapasan kronis, dan kanker lebih mungkin mengembangkan penyakit serius (WHO, 2020).

Sebagaimana diketahui, penyebaran virus Corona (Covid-19) semakin hari semakin masif dan mengkhawatirkan. Virus ini dapat menyerang semua usia baik tua maupun muda. Di Indonesia, penularan virus corona terkonfirmasi sejak awal Maret 2020 dan terus bertambah sampai akhir April 2020. Dalam waktu sekitar satu setengah bulan, jumlah kasus positif telah mencapai lebih dari 10.118 kasus (Nurfajriani, 2020).

Aceh merupakan daerah yang beresiko tinggi terkena dampak Covid-19. Jumlah kasus positif 
di Aceh per 30 April 2020 telah mencapai 10 kasus (Tide, 2010). Jumlah kasus positif yang masih tergolong sedikit dibandingkan beberapa daerah lain di Indonesia. Kondisi ini, membuat masyarakat masih kurang peduli tentang bahayanya virus ini. Hal ini ditandai dengan masih aktifnya pergerakan masyarakat dari satu tempat ke tempat yang lain. Masyarakat masih cenderung mengabaikan himbauan pemerintah setempat terkait pencegahan penularan Covid19. Oleh karena itu, kegiatan edukasi terkait pencegahan penularan virus kepada masyarakat masih harus dilakukan mengingat bahwa wabah ini bukan sekedar pandemi biasa.

Pada dasarnya, Pemerintah telah melalukan berbagai usaha preventif terhadap penularan Covid19 seperti himbauan pemakaian masker, mencuci tangan dengan hand sanitizer, menjaga jarak fisik (physical distancing), dan bekerja dari rumah (work from home) (Indonesia, 2020). Himbauan memakai masker dan mencuci tangan dengan hand sanitizer, disisi lain berdampak pada ketersediaan kedua produk tersebut yang menjadi barang langka di tengah ancaman pandemi Covid-19 (Safira Dita, 2020). Selain itu, pandemi Covid-19 juga berdampak pada perputaran perekonomian tanah air, khususnya pada masyarakat kecil yang kesulitan untuk mencari penghasilan (Bariah, 2020). Gangguan ekonomi yang masif yang diakibatkan oleh virus ini telah mempengaruhi tenaga kerja dunia sebesar 3,3 miliar pekerja. Oleh karena itu terjadinya penurunan drastis dari kegiatan ekonomi dalam lapangan pekerjaan, baik dalam hal pekerjaan, jumlah pekerja, jam kerja dan gaji pokok pekerja (Nabila, 2020)

Salah satu masyarakat terdampak ekonomi akibat pandemi Covid-19 adalah masyarakat Desa Surien, Banda Aceh. Sebagian besar penduduk bermata pencaharian sebagai Nelayan dan buruh lepas lainnya. Akibat pembatasan sosial dan aktivitas dikarenakan Covid 19 tentunya telah berdampak negatif bagi perekonomian masyarakat desa tersebut. Selain itu pemahaman masyarakat setempat mengenai pandemi Covid-19 juga masih perlu diedukasi lebih lanjut. Dengan demikian, sosialisasi terkait pencegahan penularan Covid-19 dan bantuan penguatan ekonomi masyarakat terdampak di Desa Surien Kecamatan Meuraxa Kota Banda Aceh perlu dilakukan

\section{Metode Pelaksanaan}

Kegiatan pengabdian kepada masyarakat ini dilaksanakan di Desa Surien Kecamatan Meuraxa Kota Banda Aceh. Pelaksanaan pengabdian dimulai persiapan, sosialisasi dan pemberian bantuan ekonomi. dari pendekatan mitra pengabdian, perizinan, penyiapan materi, pelaksanaan sosialisasi dan juga evaluasi.

\subsection{Persiapan}

Pada tahap ini terdiri dari pemilihan desa sebagai daerah pengabdian, pendekatan desa pengabdian, perizinan, penyiapan materi dan juga penyiapan paket bantuan sembako. Pemilihan desa dilakukan dengan melihat mayoritas mata pencaharian penduduk desa. Salah satu desa di Kota Banda Aceh yang penduduknya sebagian besar berprofesi nelayan dan buruh lepas harian adalah Desa Surien. Selanjutnya dalam penyiapan materi sebagai bahan persiapan sosialisasi diambil dari jurnal dan juga website Lembaga Kesehatan. Dalam penyiapan paket bantuan sembako, tim pengabdian membeli pada toko grosir sembako di wilayah Kota Banda Aceh. 

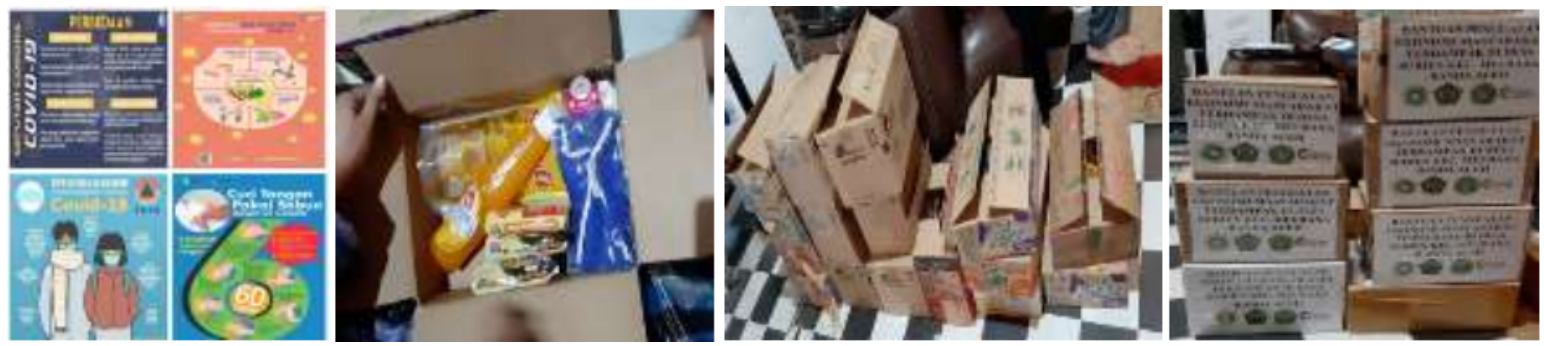

Gambar 1. Persiapan perlengkapan untuk sosialisasi dan bantuan sembako

\subsection{Sosialisasi}

Penyampaian materi dilakukan dengan dua cara yaitu presentasi dan pembagian brosur. Materi yang dipersiapkan disampaikan secara ringkas dan jelas agar mudah dipahami oleh masyarakat.

\subsection{Pemberian paket bantuan ekonomi}

Masyarakat yang menerima paket bantuan ekonomi adalah penduduk yang layak untuk mendapatkan bantuan seperti janda, anak yatim serta buruh lepas dan nelayan

\section{Pelaksanaan Pengabdian}

\subsection{Sosialisasi}

Sebagai bentuk kepedulian terhadap permasalahan mitra, salah satu langkah awal yang dilakukan tim pelaksana adalah kegiatan sosialisasi penanggulangan dampak Covid-19 khusunya dalam mengurangi penyebaran virus. Pelaksanaan kegiatan mengikuti protokol kesehatan yang telah ditetapkan pemerintah yaitu masyarakat harus memakai masker serta jarak antar orang minimal satu atau dua meter untuk mengantisipasi penularan virus corona (Adrian, 2020). Hal ini dilakukan untuk semua aktivitas yang dilakukan selama pengabdian.

Sosialisasi juga dilakukan di ruangan terbuka yaitu di halaman Kantor Keuchik Desa Surien. Sosialisasi dilakukan dengan 2 cara yaitu:

1. Penjelasan langsung

2. Pembagian brosur

Adapun isi sosialisasi secara garis besar mengenai penularan dan pencegahan virus corona yaitu dengan pemakaian masker dan pencucian tangan yang benar.

Virus Corona dapat ditularkan melalui tetesan kecil dari hidung atau mulut ketika seseorang yang terinfeksi virus mengalami batuk dan bersin (CNBC Indonesia, 2020). Oleh karena pengedukasian masyarakat tentang pemasangan masker yang benar perlu dilakukan. Sosialisasi pemasangan masker dilakukan melalui praktik langsung didepan masyarakat penerima bantuan penguatan ekonomi. Selain itu juga pengetahuan tentang kapan perlu dan tidaknya penggunaan masker juga termasuk dalam sosialisasi. Selain pemasangan masker, cara mencuci tangan yang baik dan benar juga dijelaskan karena untuk membunuh virus dapat dilakukan dengan sering mencuci tangan dengan sabun dan air (BBC Redaksi, 2020). Selanjutnya pengetahuan tentang bahaya virus, penularan dan pencegahan juga diedukasikan kepada masyarakat. Tim pelaksana juga membagikan produk masker dan sabun cuci tangan agar masyarakat dapat mempraktikkan secara langsung mengikuti arahan. Seperti yang dijelaskan sebelumnya, cara kedua sosialisasi yaitu dengan memberikan brosur yang menarik tentang cara mencuci tangan, pemakaian masker dan juga protokol pencegahan virus corona. Brosur ini diselipkan ke dalam paket bantuan ekonomi. 


\subsection{Penguatan Ekonomi}

Dalam penguatan ekonomi masyarakat Desa Surien ditengah pandemi, maka dilakukan pemberian paket bantuan berupa sembako. Pemberian sembako diharapkan dapat membantu masyarakat yang pada saat itu menjalani puasa Ramadhan dan juga sebagai wujud penguatan ekonomi masyarakat terdampak karena tidak bisa dipungkiri ditengah kondisi sekarang ini, bantuan sembako sangat dibutuhkan oleh warga khususnya mereka yang kehilangan pekerjaan akibat dampak pandemi ini (Gatra Redaksi, 2020)

Kegiatan ini diharapkan dapat berkontribusi terhadap pencegahan penyebaran dan mengurangi dampak COVID-19.

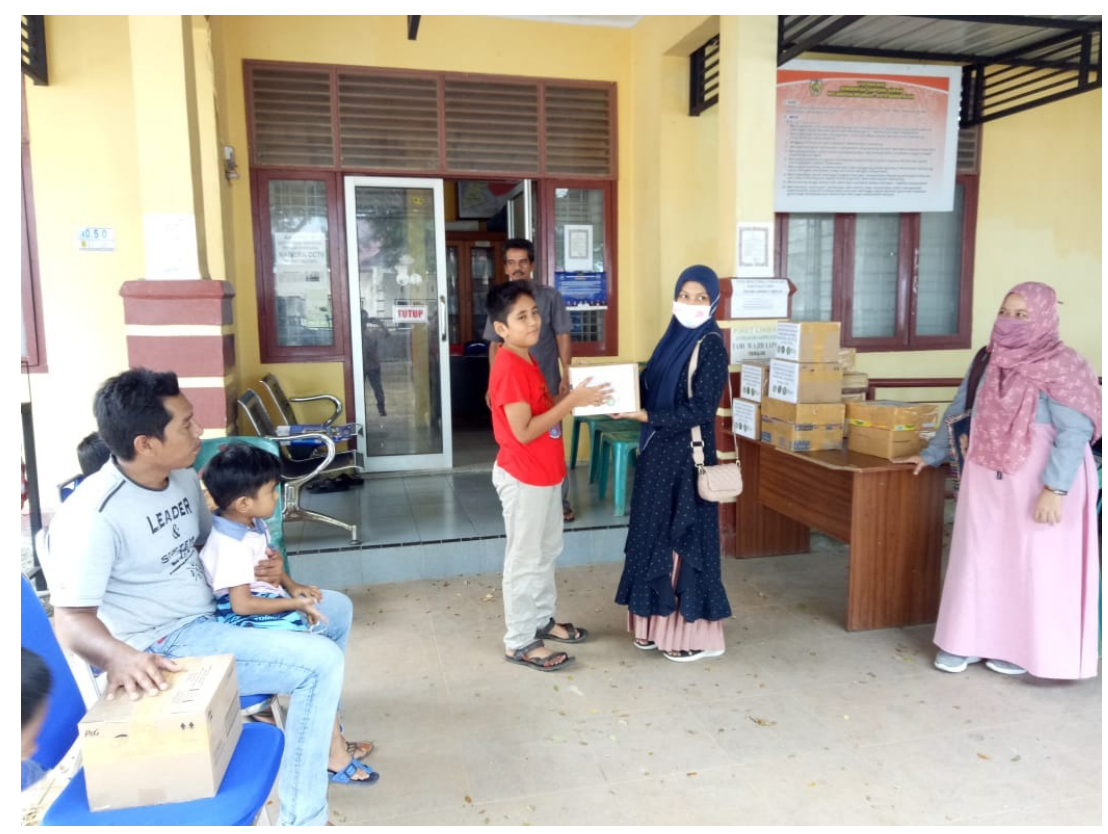

Gambar 2. Pemberian Paket Sembako

\section{Hasil dan Pembahasan}

Dari hasil pengabdian dapat diketahui bahwa masyarakat pada saat dilakukan pengabdian memang belum terlalu peduli akan pencegahan virus, mereka masih tidak menggunakan masker dalam menerima bantuan. Oleh karena itu dengan adaya sosialisasi ini masyarakat menjadi lebih memahami bagaimana penyebaran Covid-19 dan cara pencegahannya melalui pemakaian masker yang benar juga cara mencuci tangan yang tepat. Pemahaman diukur melalui praktik yang dilakukan masyarakat sesuai arahan tim pelaksana. Dari praktik tersebut masyarakat sudah mengetahui bagaimana pemakaian masker dan cuci tangan sesuai standar WHO. Selain itu, masyarakat juga mendapat pengetahuan secara umum mengenai virus corona, dimana dan kapan virus muncul pertama kali, cara penyebarannya yang sangat cepat melalui droplet batuk dan bersin serta cara pencegahan penularan virus. Dari hasil pengabdian juga dapat dilihat keantusiasan peserta dalam mengikuti sosialisasi yang dilakukan. Hal ini diukur dari kehadiran masyarakat sesuai dengan target pengabdian. Target pengabdian dihadiri oleh perwakilan masyarakat yaitu perangkat desa dan juga mereka yang berasal dari keluarga yang kurang mampu dan kurang pemahaman tentang pandemi virus.

Selain dari pengedukasian masyarakat mengenai virus dan pencegahannya, tim pelaksana juga 
memberikan bantuan paket sembako yang dirasa sangat bermanfaat bagi mereka yang tidak berpenghasilan karena harus tetap berada di rumah selama isu pandemi Covid-19. Pengabdian juga dilaksanakan tepat pada Bulan Ramadhan sehingga pemberian paket bantuan sembako sangat diperlukan.

Masyarakat yang diwakili oleh perangkat desa dan perwakilan penduduk kurang mampu Desa Surien sangat berterima kasih atas terlaksananya kegiatan ini karena mereka dapat memahami lebih lanjut tentang pandemi virus yang telah tersebar di dunia. Selain itu mereka juga sangat bersyukur mendapatkan paket bantuan sembako dalam Bulan Ramadhan dan juga ditengah kondisi yang tidak stabil akibat virus.

Setelah sosialiasi dilaksanakan, tim pelaksana juga melakukan evaluasi sebagai bahan masukan terhadap pelaksanaan pengabdian-pengabdian kedepan.

\section{Kesimpulan}

Berdasarkan hasil kegiatan pengabdian kepada masyarakat, "Sosialisasi Pencegahan Penularan Covid-19 dan Bantuan Penguatan Ekonomi Masyarakat Terdampak di Desa Surien Kecamatan Meuraxa Kota Banda Aceh" ini berjalan dengan lancar. Masyarakat sangat bersemangat mengikuti kegiatan ini. Setelah mengikuti sosialisasi, masyarakat semakin memahami pentingnya memakai masker dan cuci tangan yang benar untuk pencegahan dini penyebaran Covid-19. Pemberian bantuan paket sembako sangat bermanfaat untuk penguatan ekonomi masyarakat yang cenderung tidak berpenghasilan selama isu pandemi Covid-19, terutama di bulan suci Ramadhan pada saat sosialisasi dilaksanakan. Secara keseluruhan, kegiatan ini sangat bermanfaat bagi pelaksana dan mitra dalam pencegahan penyebaran dan mengurangi dampak COVID-19 bagi masyarakat setempat.

\section{Referensi}

Adrian, K. (2020). Pentingnya Menerapkan Social Distancing Demi Mencegah COVID-19. Alodokter.Com.

Bariah, C. (2020). Pengaruh Corona Terhadap Kehidupan Sosial Masyarakat. Serambinews. https://aceh.tribunnews.com/2020/03/21/pengaruh-corona-terhadap-kehidupan-sosialmasyarakat

BBC Redaksi. (2020). Virus corona: Tips terlindung dari Covid-19 dan mencegah penyebaran sesuai petunjuk WHO. BBC Indonesia. https://www.bbc.com/indonesia/vert-fut-51956329

CNBC Indonesia, R. (2020). Awas, Ini Cara Penyebaran Virus Corona Covid-19 versi WHO. CNBC Indonesia.

Gatra Redaksi. (2020). Sembako Sangat Dibutuhkan Warga Terdampak Pandemi Corona. Gatra. https://www.gatra.com/detail/news/478089/kebencanaan/sembako-sangat-dibutuhkanwarga-terdampak-pandemi-corona

Nabila, S. (2020). Dampak Covid-19 Terhadap Tenaga Kerja di Indonesia. Reserchgate.

Nurfajriani, R. (2020). Update Kasus Virus Corona di Indonesia per Kamis, 30 April 2020: 10.118 Positif COVID-19. Pikiran Rakyat. https://www.pikiran-rakyat.com/nasional/pr01374208/update-kasus-virus-corona-di-indonesia-per-kamis-30-april-2020-10118-positifcovid-19

Safira Dita. (2020). Stok Masker dan Hand Sanitizer Langka Akibat Virus Corona, Oknum yang Ketahuan Menimbun Terancam Hukuman 5 Tahun Penjara. HITS. 
https://hits.grid.id/read/482047795/stok-masker-dan-hand-sanitizer-langka-akibat-viruscorona-oknum-yang-ketahuan-menimbun-terancam-hukuman-5-tahun-penjara?page=all .

Tide, R. H. R. (2010). Bolt shear design considerations. Engineering Journal.

WHO. (2020). Coronavirus disease (COVID-19) outbreak. Emergencies - Diseases. 